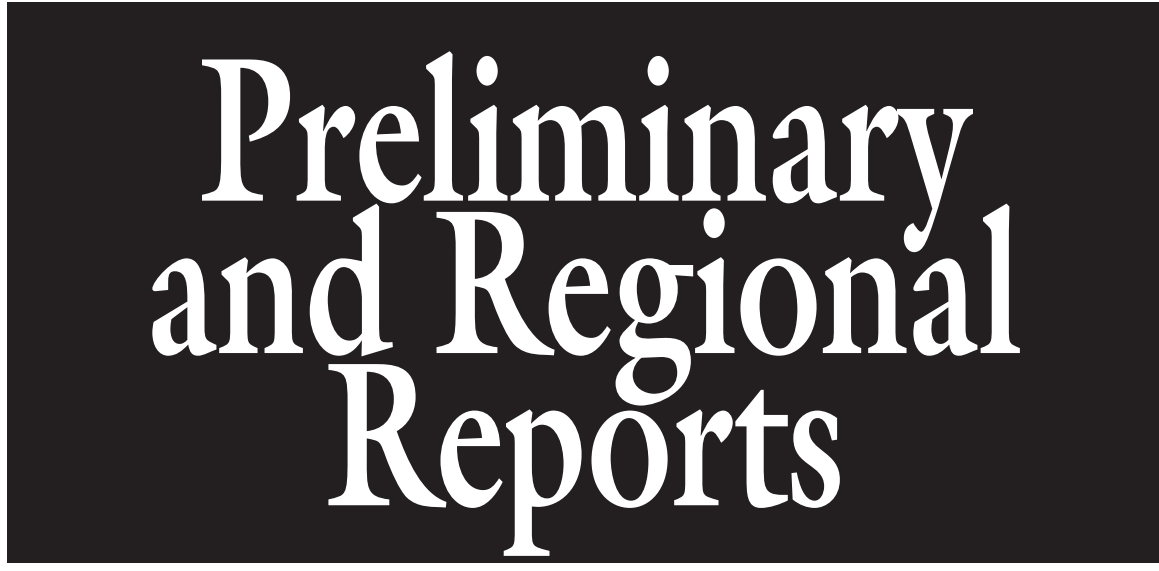

\title{
Evaluation of Growth, Flowering, and Cold Hardiness of Ceanothus in Western Oregon
}

\author{
Neil C. Bell ${ }^{1}$
}

AdDitional InDEX wORDs. drought, landscape, shrubs, wild lilac, California lilac

\begin{abstract}
Summary. Thirty-eight species, cultivars, and hybrid selections of ceanothus (Ceanothus spp.) were evaluated for growth, flowering, and cold hardiness in a landscape trial in Silverton, OR, from 2001 to 2005. Plants were only irrigated for establishment in Summer 2001 and were not pruned or fertilized throughout the trial. Several cultivars showed dieback and leaf damage after $22{ }^{\circ} \mathrm{F}$ cold events in late October and early Nov. 2002 and 2003, the most severely affected of which were Ceanothus thyrsiflorus var. griseus, C. thyrsiflorus var. griseus 'Yankee Point', Ceanothus hearstiorum, and C. thyrsiflorus 'Snowflurry'. Among the cultivars evaluated, those recommended for early bloom are 'Ray Hartman' and 'Blue Jeans'. Several cultivars are effective drought-tolerant groundcovers, including 'Wheeler Canyon', 'Joyce Coulter', and 'Joan Mirov'. Among the smaller-growing plants, Ceanothus cuneatus var. rigidus 'Snowball' and Ceanothus gloviosus 'Heart's Desire' made effective groundcovers only 0.6 and $0.2 \mathrm{~m}$ tall, respectively.
\end{abstract}

$\mathrm{T}$ The genus Ceanothus, also known as wild lilac or simply ceanothus, comprises $\approx 55$ species of woody shrubs native to North America (Hardig et al., 2000). The distribution of species is concentrated in western North America, particularly in California, where they are an important component of semiarid forest, oak woodland, and chaparral. The majority of the species are evergreen

\footnotetext{
Oregon State University Extension Service, Marion County, Salem, OR 97301

I would like to acknowledge financial support from the Washington State Department of Agriculture, donation of plants by California Flora Nursery (Fulton, CA), Suncrest Nursery (Watsonville, CA), Native Sons Nursery (San Luis Obispo, CA), and Monrovia Nursery (Dayton, OR), technical assistance from the Oregon Garden, Silverton, OR, assistance with plot maintenance and data collection by Oregon State University Marion County Master Gardeners, and assistance with statistical analysis provided by Bernadine Strik, Professor of Horticulture, Oregon State University.

${ }^{1}$ Corresponding author. E-mail: neil.bell@oregonstate.
} edu. shrubs, which range in habit from prostrate to sprawling or erect large shrubs, although some may be found as small trees (Schmidt, 2003). The climate in the California floristic province in which many of the species of ceanothus originated is Mediterranean, with mild, rainy winters and warm to hot, dry summers. As a result, ceanothus is adapted to growing in hot, dry situations, often in relatively poor soils.

Few ceanothus cultivars are grown or used extensively in landscapes in western Oregon or
Washington. The most commonly grown are Ceanothus gloriosus and 'Skylark' (synonym 'Victoria'), which are a groundcover and large shrub, respectively. The genus is perceived as short-lived and tender. This reputation may partly be a result of the limited selections cultivated, but may also be attributed to plants being grown in landscapes that are watered regularly in summer-a common practice in arid regions of the western United States. Another challenge for landscape management is the large size to which 'Skylark' typically grows. An individual shrub may be more than $6 \mathrm{ft}$ tall and wide after only 5 to 7 years, particularly when irrigated; this size is impractical for some landscapes and gardens.

Little specific information on the cold hardiness of species of ceanothus cultivars is available. An estimation of winter hardiness can be inferred from the native range of species or individual clones. Fross and Wilken (2006) provide anecdotal information on a number of cultivars based on experiences in California and the United Kingdom. A field trial of 40 cultivars in Holland, which included evergreen and hybrid cultivars, found all hardy to at least U.S. Department of Agriculture (USDA) zone 8b (Hop, 2006). Boorse et al. (1998) studied the hardiness of four chaparral shrubs, including Ceanothus megacarpus, a species found in southern California and the Channel Islands, and Ceanothus spinosus, a widespread species found from Eldorado County in the Sierra Nevada foothills south into Baja California. Their research concluded that adult plants of each species showed greater resistance to cold than seedlings. Langan et al. (1997) examined the relationship between cold hardiness and drought stress in C. megacarpus and concluded that both factors needed to be considered as limiting survival and distribution of the species. In studies of potted 'Autumnal Blue' ceanothus, plant survival was diminished by

\begin{tabular}{llll}
\hline $\begin{array}{l}\text { Units } \\
\begin{array}{l}\text { To convert U.S. to SI, } \\
\text { multiply by }\end{array}\end{array}$ & U.S. unit & SI unit & $\begin{array}{l}\text { To convert SI to U.S., } \\
\text { multiply by }\end{array}$ \\
\hline 0.4047 & $\mathrm{acre}(\mathrm{s})$ & $\mathrm{ha}$ & 2.4711 \\
0.3048 & $\mathrm{ft}$ & $\mathrm{m}$ & 3.2808 \\
3.7854 & $\mathrm{gal}$ & $\mathrm{L}$ & 0.2642 \\
2.54 & inch(es) & $\mathrm{cm}$ & 0.3937 \\
1 & $\mathrm{ppm}$ & $\mathrm{mg} \cdot \mathrm{kg}^{-1}$ & 1 \\
$\left({ }^{\circ} \mathrm{F}-32\right) \div 1.8$ & ${ }^{\circ} \mathrm{F}$ & ${ }^{\circ} \mathrm{C}$ & $\left(1.8 \times{ }^{\circ} \mathrm{C}\right)+32$
\end{tabular}


increased duration of freezing and smaller container size (Cameron and Dixon, 1997). The objectives of this trial were to evaluate ceanothus cultivars under field conditions for cold hardiness, growth, and flowering in western Oregon.

\section{Materials and methods}

Species and cultivars of ceanothus were obtained from nurseries in California and Oregon in Oct. 2000 and May 2001 (Table 1). The plants were growing in 2.5-inch tree bands or 1-gal pots. The trial was located at the Oregon Garden, Silverton, OR (lat. $44^{\circ} 59^{\prime} \mathrm{N}$, long. $122^{\circ} 47^{\prime} \mathrm{W}, 440$ $\mathrm{ft}$ elevation). The evaluation site was $\approx \mathrm{l} / 4$ acre, sloping slightly westward. The soil was coarse construction fill remaining from the building of nearby wetlands. Before planting, the site was bladed off using a bulldozer and the top $\mathrm{l} f \mathrm{ft}$ was ripped and roughly graded. Three soil samples, consisting of three subsamples to a 6-inch depth each, were collected from the east, center, and west side of the site in June 2007. The soil was classified as clay with a $\mathrm{pH}$ of 5.6 (Table 2).

The trial was divided into five unequal length rows, spaced $10 \mathrm{ft}$ apart, orientated east to west. Individual plants were randomly assigned to rows and were planted $5 \mathrm{ft}$ apart within rows. Cultivars were planted in a completely randomized design with three replicates of each cultivar.

After planting on 25 May 2001, plants were mulched with medium grade douglas fir (Psendotsuga menziesii) bark to a depth of 3 inches, and were watered individually, by hand, through Sept. 2001. Plants received no supplemental irrigation from Sept. 2001 to Oct. 2005. No fertilizer was applied after planting for the duration of the trial. Plants were not pruned. Weed management included hand weeding and spot use of glyphosate, when needed.

Data collected included plant height, flowering season, and cold hardiness evaluation. Plant height (ground level to tallest shoot) and width (mean of the widest diameter and width perpendicular to the widest diameter) were measured twice per year, in Apr. and Oct. 2001 through 2004 and again in Apr. 2005. Flowering season was evaluated by recording the date of $5 \%, 50 \%$, and $100 \%$ total bloom. These data were used to calculate length of flowering season (days from $5 \%$ to $100 \%$ bloom) from 2003 through 2005. Flowering evaluation generally commenced in March for the early cultivars and continued through July for lateblooming cultivars. Cold hardiness evaluations were done in early Spring after mild weather allowed for full symptom development from any prior cold injury. Data were collected only in Spring 2003 and 2004, as there was no apparent damage following the winters of 2001-02 and 2004-05. Winter cold damage was rated on a 0 to 5 scale, adapted from Lonard and Judd (1991) with $0=$ no damage, $l=$ minor leaf damage (browning), 2 = leaf and stem damage restricted to the exterior $30 \%$ of the plant, $3=$ leaf and stem damage to the exterior $60 \%$ of the plant, $4=$ plant was killed to the ground and was resprouting, $5=$ plant was killed. Regional weather data were obtained from the Bureau of Reclamation Agrimet weather station in Aurora, OR (U.S. Bureau of Reclamation, 2008), 25 miles north of the research site.

Growth data were analyzed using repeated measures PROC GLM. Plant size was significantly affected by year in all cultivars, thus data were analyzed by year with mean comparisons using protected least significant difference (LSD) to describe differences between cultivars (version 9.1; SAS Institute, Cary, NC). The dates of $5 \%, 50 \%$, and $100 \%$ bloom and duration of bloom were analyzed using PROC GLM with mean comparisons using protected LSD. Data for size and flowering are presented in tables and figures as means and standard errors. Growth data, height, and average width, are presented for the last measurement date, 14 Apr. 2005 when plants were mature. Flowering data are presented for 2005. Cold hardiness data are presented as means with standard deviations.

\section{Results and discussion}

Ceanothus cultivars became established, grew, and filled in the rows by 2005 . A small part of the trial area at the west end was subject to periodic flooding because of runoff from a nearby road after rainfall, resulting in death of several cultivars. Three cultivars were damaged to varying degrees by deer that grazed heavily, reducing the data available ('Marie Simon' and 'Henri Desfosse') or requiring elimination from the trial ('Cliff Schmidt'). No other ceanothus cultivars suffered any noticeable feeding damage. No serious insect pest problems were noted during the trial, and disease problems were infrequent. 'Autumnal Blue' grew well early in the trial, but severe defoliation was observed starting in 2003. This resulted in the loss of all but the current season's leaves, leaving this cultivar sparsely foliated and unacceptable for landscape use. The pathogen Cercospora sp. (possibly $C$. ceanothi) was isolated from the affected leaves (Oregon State University Plant Diagnostic Clinic, Corvallis, OR) and was assumed to be the cause.

Individual plants were lost during the trial for undetermined causes, including two of the three Ceanothus velutinus var. velutinus, although the third plant grew and flowered well. This is a montane species and though the origin of the clone was unknown, it may not be particularly well-adapted to clay soils and the climate at low elevation. Individual hybrids of Ceanothus impressus, 'Julia Phelps' and 'Dark Star', died during the study. Plants derived from this species are generally regarded as preferring welldrained soils (Fross and Wilken 2006) and possibly were unsuitable for the constructed clay soil on the evaluation site (Table 2).

Plant growth. In Spring 2005, many plants had filled their allocated space and some were beginning to grow into one another. Plant height data in Spring 2005 are presented in Fig. 1 and corresponding width data are presented in Fig. 2. There was a significant effect $(P<0.0001)$ of cultivar on height and width. The results show that ceanothus as a group have a wide range of vigor and growth habit and can be divided into four broad groups based on growth habit: 1) upright shrubs; 2) large, rounded shrubs; 3 ) mounding, wide spreading shrubs; and 4) low, spreading groundcovers.

Of the upright shrubs, 'Ray Hartman' is not commonly available in the Pacific northwestern United States, but blooms heavily and proved more cold hardy than its parentage (Ceanothus arboreus $\times$ Ceanothus thyrsiflorus var. griseus) would suggest (Table 3 ). 'Ray Hartman' was unaffected by wind 
Table 1. Origin and description of ceanothus species and cultivars evaluated in a landscape trial in Silverton, OR, $2001-05$.

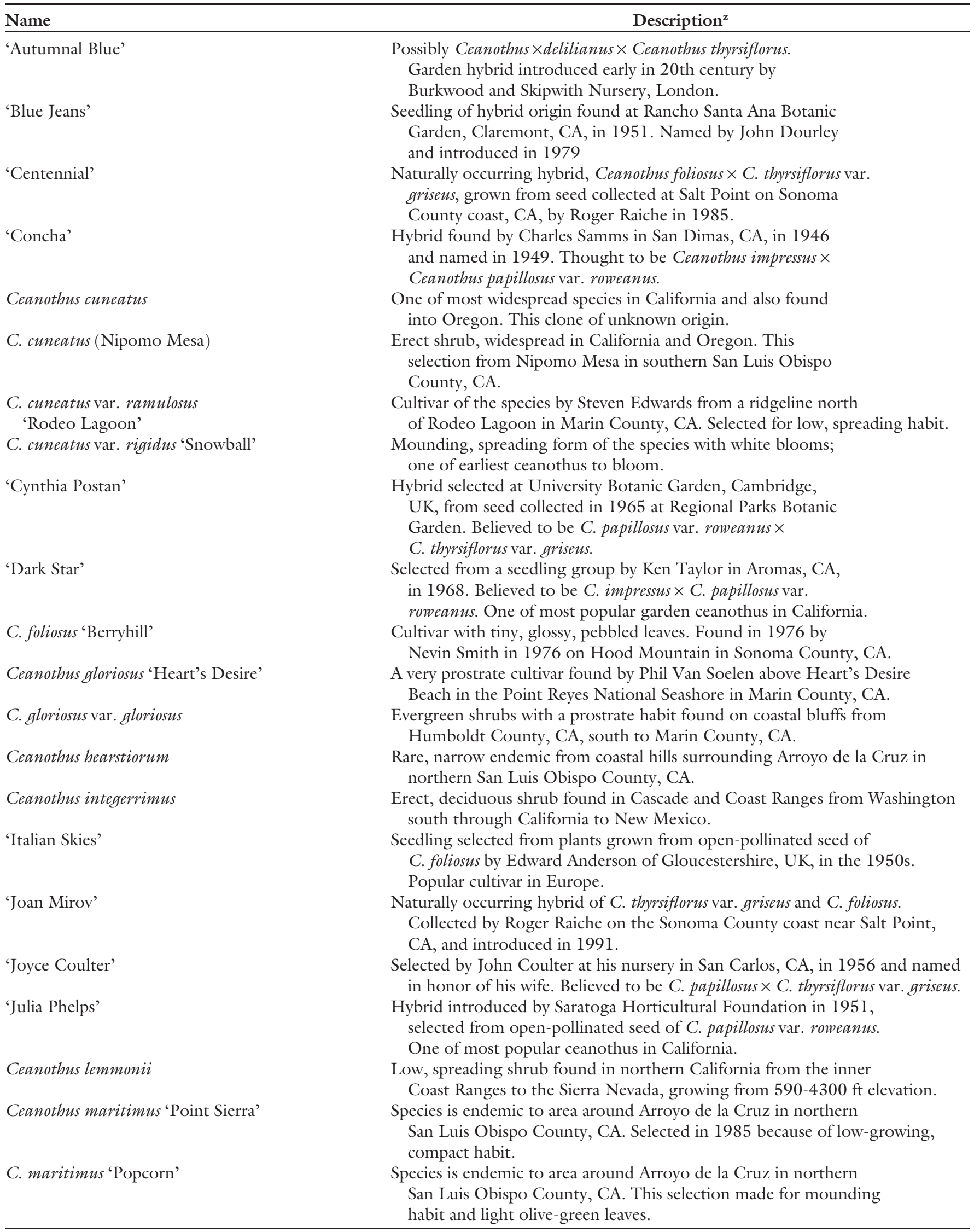


Table 1. (Continued) Origin and description of ceanothus species and cultivars evaluated in a landscape trial in Silverton, OR, 2001-05.

\begin{tabular}{|c|c|}
\hline Name & Description $^{z}$ \\
\hline 'Puget Blue' & $\begin{array}{l}\text { Selection made at University Of Washington Botanic } \\
\text { Garden from open-pollinated seed of C. papillosus var. roweanus. }\end{array}$ \\
\hline 'Ray Hartman' & $\begin{array}{l}\text { Hybrid of Ceanothus arboreus and C. thyrsiflorus var. griseus, introduced } \\
\text { by Saratoga Horticultural Foundation in } 1954 \text {. }\end{array}$ \\
\hline 'Remote Blue' & $\begin{array}{l}\text { Hybrid from Las Pilitas Nursery, Santa Margarita, CA, introduced in } 1991 \text {. } \\
\text { Believed to be Ceanothus oliganthus } \times \text { C. thyrsiflorus var. griseus. }\end{array}$ \\
\hline 'Skylark' & $\begin{array}{l}\text { Introduced by Mitch Nursery, Aurora, OR, and named in the } 1970 \mathrm{~s} \text {. } \\
\text { Evergreen shrub growing to } 8 \times 8 \mathrm{ft} \text {. Name is considered } \\
\text { synonymous with 'Victoria'. }\end{array}$ \\
\hline $\begin{array}{l}\text { C. thyrsiflorus var. griseus } \\
\text { (prostrate selection) }\end{array}$ & $\begin{array}{l}\text { Evergreen shrub distributed from Santa Barbara County, CA, north to } \\
\text { Coos County, OR. This clone is a prostrate selection of C. thyrsiflorus var. } \\
\text { griseus of unknown origin. }\end{array}$ \\
\hline $\begin{array}{l}\text { C. thyrsiflorus var. griseus } \\
\text { 'Louis Edmunds' }\end{array}$ & $\begin{array}{l}\text { Selection made in } 1942 \text { by Louis Edmunds from a group of plants } \\
\text { growing at the entrance to the Regional Parks Botanic Garden, Berkeley, CA. }\end{array}$ \\
\hline $\begin{array}{l}\text { C. thyrsiflorus var. griseus } \\
\text { 'Yankee Point' }\end{array}$ & $\begin{array}{l}\text { Selection from Yankee Point in northern Monterey County, CA, made in } \\
1954 \text { by Maunsell Van Rensselaer. Selected for low-growing } \\
\text { habit and rapid growth. }\end{array}$ \\
\hline $\begin{array}{l}\text { C. thyrsiflorus var. thyrsiflorus } \\
\text { 'Arroyo de la Cruz' }\end{array}$ & $\begin{array}{l}\text { Selection made by Nevin Smith from Arroyo de la Cruz in northern } \\
\text { San Luis Obispo County, CA, in 1981. Introduced by Wintergreen Nursery. }\end{array}$ \\
\hline $\begin{array}{l}\text { C. thyrsiflorus var. thyrsiflorus } \\
\text { 'El Dorado' }\end{array}$ & $\begin{array}{l}\text { Variegated plant that originated as a branch sport on C. thyrsiflorus var. } \\
\text { thyrsiflorus 'Zanzibar' at Yoder Toddington in Littlehampton, UK, in } 1996 .\end{array}$ \\
\hline $\begin{array}{l}\text { C. thyrsiflorus var. thyrsiflorus } \\
\text { 'Snowflurry' }\end{array}$ & $\begin{array}{l}\text { Selection from the Big Sur coast, CA, made by Joseph Solomone in } 1975 \\
\text { and introduced in 1977. One of most commonly grown white-flowering } \\
\text { ceanothus in California. }\end{array}$ \\
\hline Ceanothus $\times$ pallidus 'Marie Simon' & $\begin{array}{l}\text { Selected in 19th Century from hybids of Ceanothus herbaceus } \times \\
\text { Ceanothus } \times \text { delilianus. This cultivar has strong pink flowers and robust habit. }\end{array}$ \\
\hline
\end{tabular}

${ }^{\mathrm{z}} 1 \mathrm{ft}=0.3048 \mathrm{~m}$.

Table 2. Soil texture, $\mathrm{pH}$, and nutrient content of the top $1 \mathrm{ft}(0.3 \mathrm{~m})$ constructed soil at the east, center, and west sections of the ceanothus evaluation site at Oregon Garden, Silverton, OR (lat. $44^{\circ} 59^{\prime} \mathrm{N}$, long. $\left.122^{\circ} 47^{\prime} \mathrm{W}\right)$.

Extractable nutrient concn $(\mathrm{ppm})^{\mathrm{y}}$

\begin{tabular}{|c|c|c|c|c|c|c|c|c|}
\hline Sample $^{\mathrm{z}}$ & Texture & $\mathrm{pH}$ & $\mathbf{P}$ & $\mathrm{K}$ & $\mathrm{Ca}$ & $\mathrm{Mg}$ & $\mathrm{Na}$ & $\mathrm{NO}_{3}$ \\
\hline East & Clay & 5.5 & 15 & 285 & 1,160 & 357 & 29 & 3.5 \\
\hline Center & Clay loam & 5.6 & 12 & 244 & 1,690 & 460 & 30 & 2.3 \\
\hline West & Clay & 5.5 & 11 & 242 & 1,130 & 310 & 29 & 4.7 \\
\hline
\end{tabular}

${ }^{2}$ Samples consist of three subsamples from east, center, and west areas of the evaluation plot, which were combined before the analysis.

${ }_{\mathrm{y}}^{\mathrm{P}}=$ phosphorus, $\mathrm{K}=$ potassium, $\mathrm{Ca}=$ calcium, $\mathrm{Mg}=$ magnesium, $\mathrm{Na}=$ sodium, $\mathrm{NO}_{3}=$ nitrate; $1 \mathrm{ppm}=1 \mathrm{mg} \cdot \mathrm{kg}^{-1}$.

or snow and retained its form and foliage. 'Blue Jeans' was noticeably smaller than 'Ray Hartman' and was of distinctive appearance, with small leaves on upright stems and very early blooming (Fig. 3).

Among the large, rounded shrubs the industry standard,
'Skylark' grew and flowered reliably. 'Italian Skies' is not as commonly grown as 'Skylark', but also grew well, although the foliage of this cultivar is 


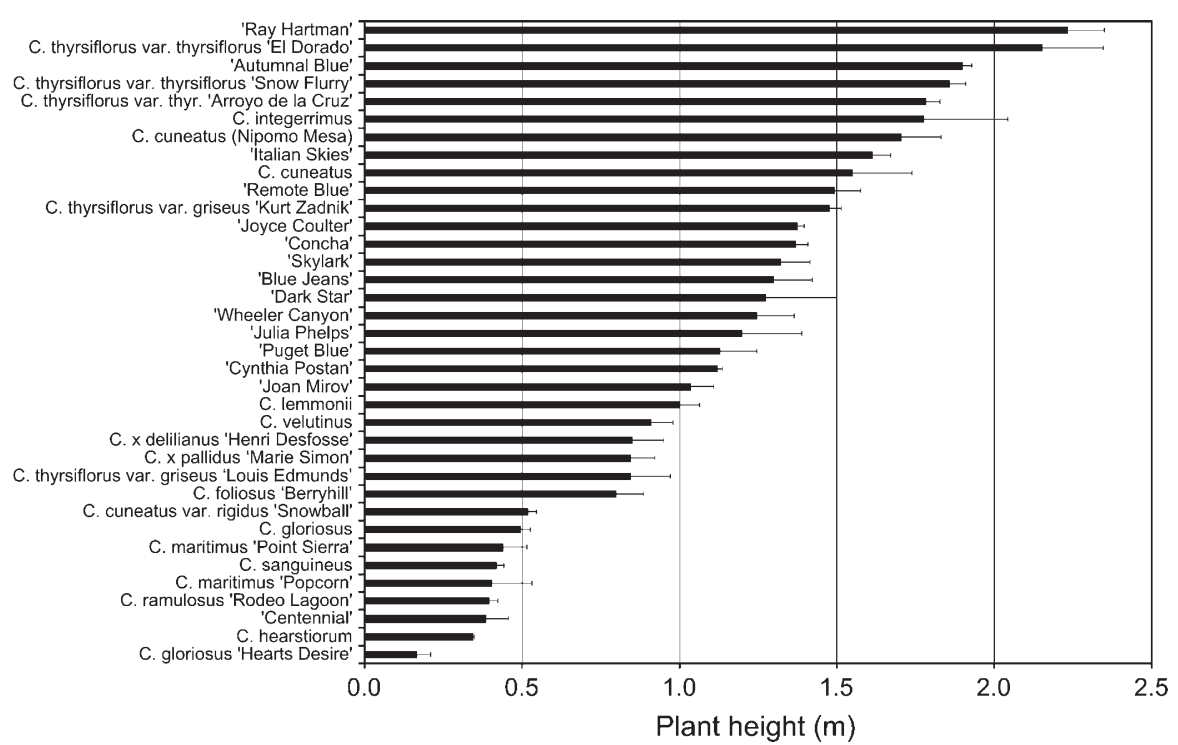

Fig. 1. Height of ceanothus after growing for 4 years in a landscape evaluation in Silverton, OR, in Spring $2005[$ mean + SE $(n=3)] ; 1 ~ m=3.3208 \mathrm{ft}$.

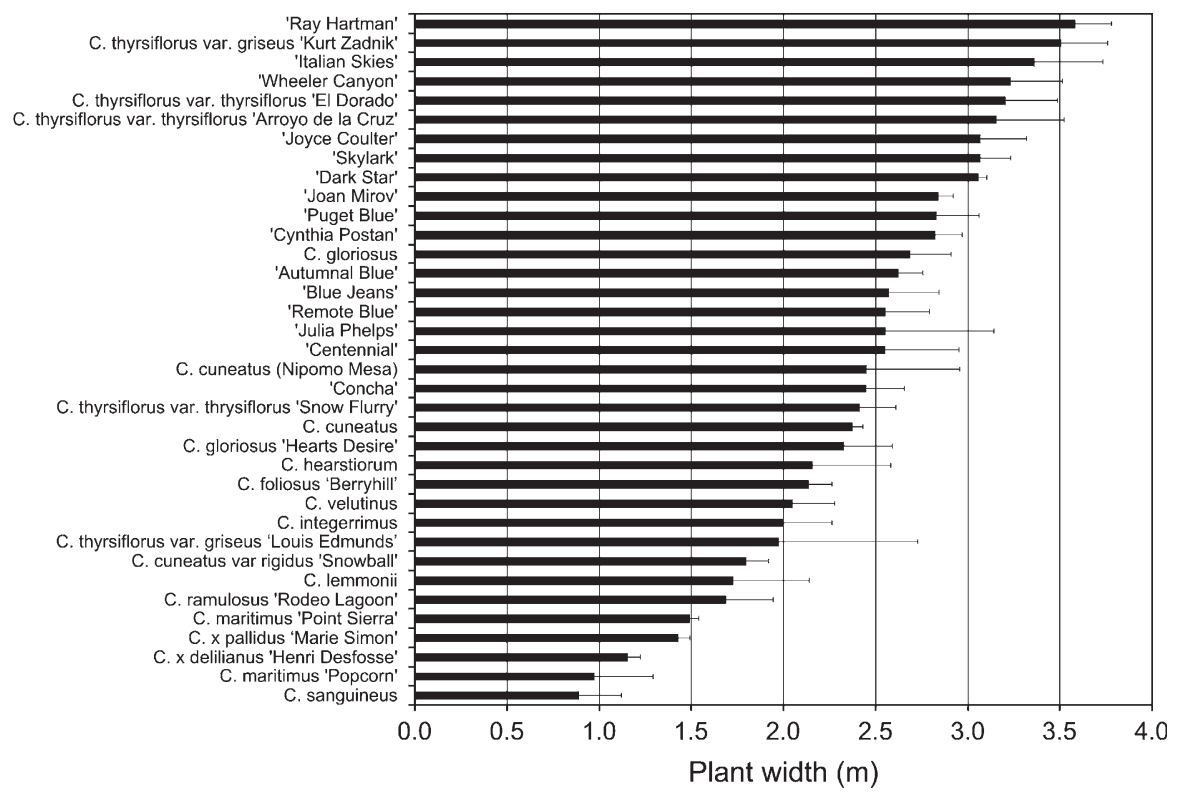

Fig. 2. Width of ceanothus after growing for 4 years in a landscape evaluation in Silverton, OR, in Spring 2005 [mean + SE $(\mathrm{n}=3)] ; 1 \mathrm{~m}=3.3208 \mathrm{ft}$.

not as attractive as 'Skylark'. 'El Dorado' is a variegated cultivar that has a tendency to revert, resulting in variegated and green shoots, although it continues to grow, flower, and retain its form. The cultivars and hybrids of C. impressus are in this group and although some of them died during the trial, they are among the best foliage and flowering plants in the genus. Ceanothus 'Concha' also typically forms a large shrub, but in this evaluation, it lacked vigor.

The third group, mounding, spreading shrubs, contains several well-known cultivars used as groundcovers in California, including 'Joyce Coulter' and 'Joan Mirov'. All of these are distinctive in appearance and would make excellent tall and widespreading groundcovers on hot, dry banks in western Oregon. Other cultivars that would be similarly useful include C. thyrsiflorus var. griseus 'Kurt Zadnik' and 'Wheeler Canyon'. They are all very wide-spreading and likely of sufficient height and density to suppress most weeds.

The lower-growing groundcovers in the trial performed inconsistently. Weed suppression with the lowest-growing cultivars, such as 'Centennial' and Ceanothus hearstiorum, was poor because of lack of height and loss of foliage due to cold injury (Table 3 ). Low-growing weeds such as dandelion (Taraxacum officinale) and quackgrass (Elytrigia repens) were able to take advantage of these openings and became difficult to eradicate. C. gloriosus 'Hearts Desire' was more cold hardy than 'Centennial' or C. hearstiorum, but was still very low-growing. These three cultivars might be most effectively used as small-scale groundcovers. Taller growing plants such as C. gloriosus and Ceanothus cuneatus var. rigidus 'Snowball' tend to be more effective groundcovers, particularly for weed control. Other lowgrowing shrubs that were hampered by cold injury included C. thyrsiflorus var. griseus and Ceanothus foliosus 'Berryhill' (Table 3).

COLD HARDINESS. The most serious damage occurred after temperatures in early Nov. 2002 dropped from average night temperature of 37 to $22{ }^{\circ} \mathrm{F}$. This was an early freeze that occurred while many plants were still growing. A similar freeze occurred on 1 Nov. 2003, when the temperature again dropped quickly from mild lows of 37 to $25^{\circ} \mathrm{F}$. Again, because of the relatively severe temperature early in the winter, serious damage occurred on a wide range of plants.

The most commonly grown clones of ceanothus, 'Skylark' and $C$. gloriosus, showed relatively little or no cold damage in this trial (Table 3 ). Similarly unaffected were the semievergreen cultivars 'Marie Simon' and 'Henri Desfosse', probably because of hardiness inherited from their Ceanothus americanus lineage (Fross and Wilken, 2006). Several of the most desirable cultivars, such as 'Remote Blue', 'Blue Jeans', and 'Wheeler Canyon' showed relatively minor leaf and twig burn from the cold events described above and they quickly recovered.

With the exception of 'Kurt Zadnik', which is a vigorous shrub, most cultivars of C. thyrsiflorus var. grisens, popular as groundcovers in California, showed severe cold damage (Table 3). C. hearstiorum also had considerable tip dieback, although the plants recovered. C. thyrsiflorus var. thyrsiflorus 'Snowflurry' is a 
Table 3. Mean cold-hardiness ratings $(n=3)$ of ceanothus evaluated in Silverton, OR, on 3 Apr. 2003 and 29 Apr. 2004 and an average over years with the SD.

\begin{tabular}{|c|c|c|c|c|}
\hline \multirow[b]{2}{*}{ Plant name } & \multicolumn{4}{|c|}{$\begin{array}{l}\text { Mean cold hardiness rating } \\
\qquad(0-5 \text { scale })^{\mathrm{z}}\end{array}$} \\
\hline & 2003 & 2004 & Avg & SD \\
\hline Ceanothus $\times$ delilianus 'Henri Desfosse' & 0.0 & 0.0 & 0.0 & 0.01 \\
\hline Ceanothus gloriosus 'Hearts Desire' & 0.0 & 0.0 & 0.0 & 0.87 \\
\hline Ceanothus $\times$ pallidus 'Marie Simon' & 0.0 & 0.0 & 0.0 & 0.01 \\
\hline Ceanothus sanguineus & 0.0 & 0.0 & 0.0 & 0.01 \\
\hline Ceanothus velutinus & 0.0 & 0.0 & 0.0 & 0.01 \\
\hline Ceanothus integerrimus & 0.0 & 0.7 & 0.3 & 0.58 \\
\hline Ceanothus cuneatus (Nipomo Mesa) & 0.0 & 1.0 & 0.5 & 0.71 \\
\hline C. cuneatus & 0.3 & 0.0 & 0.2 & 0.29 \\
\hline 'Wheeler Canyon' & 0.3 & 0.0 & 0.2 & 0.29 \\
\hline Ceanothus lemmonii & 0.3 & 0.7 & 0.5 & 0.87 \\
\hline C.gloriosus & 0.3 & 1.3 & 0.8 & 0.87 \\
\hline Ceanothus thyrsiflorus var. thyrsiflorus 'El Dorado' & 0.7 & 0.0 & 0.3 & 0.29 \\
\hline 'Skylark' & 0.7 & 0.0 & 0.3 & 0.58 \\
\hline 'Italian Skies' & 0.7 & 0.7 & 0.7 & 0.87 \\
\hline 'Cynthia Postan’ & 1.0 & 0.0 & 0.5 & 0.50 \\
\hline 'Dark Star' & 1.0 & 1.0 & 1.0 & 1.41 \\
\hline 'Remote Blue' & 1.0 & 1.3 & 1.2 & 0.96 \\
\hline 'Blue Jeans' & 1.2 & 0.2 & 0.7 & 0.77 \\
\hline 'Autumnal Blue' & 1.3 & 1.3 & 1.3 & 0.58 \\
\hline Ceanothus maritimus 'Point Sierra' & 1.3 & 1.3 & 1.3 & 0.87 \\
\hline Ceanothus ramulosus 'Rodeo Lagoon' & 1.5 & 0.0 & 0.8 & 0.35 \\
\hline 'Concha' & 1.7 & 0.0 & 0.8 & 0.76 \\
\hline 'Julia Phelps' & 1.7 & 0.0 & 1.0 & 0.76 \\
\hline 'Ray Hartman' & 1.7 & 0.0 & 0.8 & 0.29 \\
\hline C. thyrsiflorus var. grisens 'Kurt Zadnik' & 1.7 & 1.3 & 1.5 & 0.87 \\
\hline Puget Blue' & 2.0 & 1.0 & 1.7 & 0.01 \\
\hline C. thyrsiflorus var. thyrsiflorus 'Arroyo de la Cruz' & 2.0 & 2.3 & 2.2 & 0.29 \\
\hline 'Joyce Coulter' & 2.3 & 0.0 & 1.4 & 0.76 \\
\hline Ceanothus foliosus 'Berryhill' & 2.3 & 2.0 & 2.2 & 0.29 \\
\hline C. thyrsiflorus var. griseus 'Louis Edmunds' & 2.5 & 1.5 & 2.0 & 1.41 \\
\hline 'Centennial' & 2.7 & 1.3 & 2.0 & 0.87 \\
\hline 'Joan Mirov' & 2.7 & 2.0 & 2.3 & 0.76 \\
\hline C. cuneatus var. rigidus 'Snowball' & 2.7 & 2.0 & 2.4 & 0.29 \\
\hline C. maritimus 'Popcorn' & 2.7 & 3.0 & 2.8 & 1.00 \\
\hline C. thyrsiflorus var. thyrsiflorus 'Snow Flurry' & 3.0 & 3.0 & 3.0 & 0.87 \\
\hline Ceanothus hearstiorum & 3.5 & 1.0 & 2.3 & 1.06 \\
\hline C. thyrsiflorus var. griseus 'Yankee Point' & 4.0 & $\mathrm{~N} / \mathrm{A}$ & 4.0 & 0.01 \\
\hline C. thyrsiflorus var. griseus (prostrate selection) & 4.0 & $\mathrm{~N} / \mathrm{A}$ & 4.0 & 0.00 \\
\hline
\end{tabular}

${ }^{\mathrm{z}} 0=$ no visible damage, 1 = minor leaf damage, 2 = leaf and stem damage restricted to outer $30 \%$ of shrub, $3=$ leaf and stem damage restricted to outer $60 \%$ of shrub, $4=$ killed to ground with re-sprouting, $5=$ killed and not recovering.

white-flowered cultivar from the mild Big Sur coast of California (Fross and Wilken, 2006) and was much more susceptible to cold damage than other cultivars of var. thyrsiflorus. Plants of this cultivar recovered poorly from successive cold spells in 2002 and 2003 , and would thus be best suited for coastal areas. Another cultivar that showed serious cold damage in 2002 and 2003 was Ceanothus maritimus 'Popcorn', which had dieback, although plants eventually recovered. Another cultivar of this species, 'Point Sierra', had relatively little cold damage in both years, and with its blue flowers and compact habit, would make a good small-scale groundcover.

FlOWERING. Most cultivars in the trial flowered well in 2002, but analysis of data on flowering was restricted to 2003-05, when the plants were more mature. There was a significant effect of year, cultivar, and a year by cultivar interaction on date of $5 \%, 50 \%$, and $100 \%$ bloom. There was no significant effect of cultivar, year, or an interaction on duration of the flowering season.
Data on duration of flowering are presented for 2005, when plants were mature, in Fig. 3. The earliest-flowering cultivars were consistently $C$. cuneatus, C. maritimus selections ('Point Sierra' and 'Popcorn'), and 'Blue Jeans'. The specific order in which these began blooming varied from 2003 to 2005 , accounting in part for the year by cultivar interaction. Interestingly, even though the date of $5 \%$ bloom would vary from year to year because of weather conditions (data not shown), the duration of flowering did not, remaining consistent for all cultivars for each year. The most commonly grown ceanothus in the northwestern United States, C. gloriosus and 'Skylark', are early- to midseason- and mid- to late season-flowering cultivars, respectively. The flowering season can be extended several weeks earlier and later by selecting other cultivars.

Among the better early-blooming cultivars was 'Blue Jeans', which typically began flowering in early March and continued through early to mid-April. C. cuneatus is a species widespread in California and Oregon, and the form in this trial, although of unknown origin, was a shapely, medium-sized gray-leaved shrub that produced white flowers also starting in early March. Although this species is rarely cultivated in the Northwest, it is a hardy, attractive shrub of distinctive appearance because of the gray leaves. Several cultivars or hybrids of C. impressus, 'Julia Phelps', 'Dark Star', and 'Puget Blue', were among the showiest of the trial, flowering from April through mid-May. C. thyrsiflorus var. griseus 'Kurt Zadnik' was one of the most distinctive in bloom, with deep blue flowers throughout May on a tall, widespreading groundcover.

Several cultivars flowered from late May well into July, including 'Autumnal Blue', 'Marie Simon', and 'Henri Desfosse'. 'Autumnal Blue' had severe leaf spot (Cercospora sp.) that caused major defoliation, thus reducing its ornamental appeal and vigor. Although other cultivars in the evaluation may have been affected by this pathogen, no other plant was affected to the same extent. 'Marie Simon' and 'Henri Desfosse' grew and flowered well, but were grazed heavily by deer, along with 'Cliff 


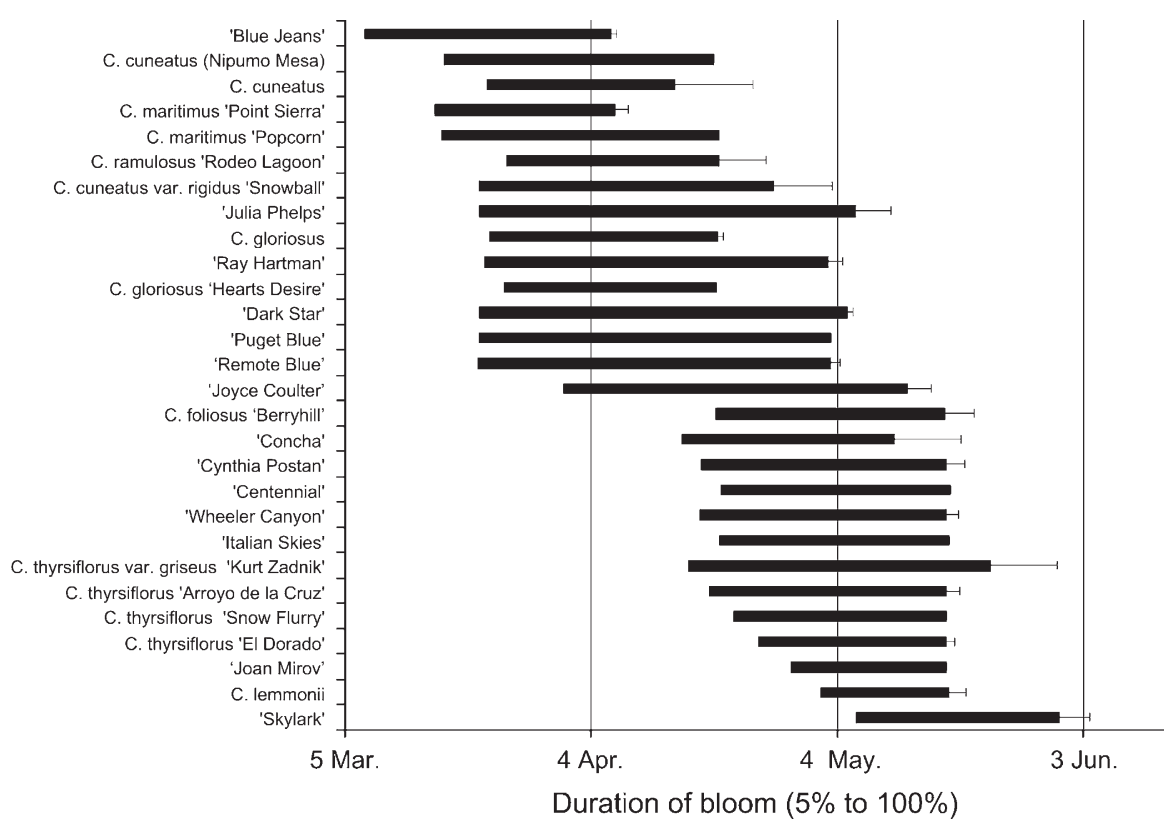

Fig. 3. Average flowering time and duration of ceanothus grown in a landscape evaluation in Silverton, OR, in 2005 [ mean + SE $(n=3)]$.

Schmidt', and like that cultivar, were eventually removed from the evaluation. If damage from deer is not likely to be an issue in a landscape, these and other cultivars of Ceanothus $\times$ delilianus and Ceanothus $\times$ pallidus are excellent ways to extend the flowering season of ceanothus into the summer months.

\section{Literature cited}

Boorse, G.C., F.W. Ewers, and S.D Davis. 1998. Response of chaparral shrubs to below-freezing temperatures: Acclimation, ecotypes, seedlings vs. adults. Amer. J. Bot. 85:1224-1230.

Cameron, R.W.F. and G.R. Dixon. 1997. Air temperature, humidity and rooting volume affecting freezing injury to $R$ hododendron and other perennials. J. Hort. Sci. 72:553-562.

Fross, D. and D. Wilken. 2006. Ceanothus. Timber Press, Portland, OR.

Hardig, T.M., P.S. Soltis, and D.E. Soltis. 2000. Diversification of the North American shrub genus Ceanothus (Rhamnaceae): Conflicting phylogenies from nuclear ribosomal DNA and chloroplast DNA. Amer. J. Bot. 87:108-123.

Hop, M.E.C.M. 2006. Ceanothussortimentsonderzoek en keuringsrapport. Dendroflora 43:80-123.

Langan, S.L., F.W. Ewers, and S.D. Davis. 1997. Xylem dysfunction caused by water stress and freezing in two species of co-occurring chaparral shrubs. Plant Cell Environ. 20:425-437.

Lonard, R.I. and F.W. Judd. 1991. Comparison of the effects of the severe freezes of 1983 and 1989 on native woody plants in the lower Rio Grande River valley, Texas. Southwest. Nat. 36:213-217.

Schmidt, C. 2003. Dr. Cliff Schmidt's treatment of the genus Ceanothus. 18 June 2008. <http://oregonstate.edu/ dept/botany/herbarium/projects / ceanothus/genus.html>.

U.S. Bureau of Reclamation. 2008. Agrimet, The Pacific Northwest Cooperative Agriculture Weather Network. 9 Aug. 2007. <http://www.usbr.gov/pn/agrimet/ webarcread.html>. 